\title{
PENGETAHUAN DAN SIKAP TENTANG PENYAKIT INFEKSI MENULAR SEKSUAL (IMS) PADA IBU RUMAH TANGGA DI PUSKESMAS TULANG BAWANG BARAT
}

\author{
Nurmala*, Idawati* \\ *Dosen Jurusan Kebidanan Poltekkes Tanjungkarang
}

\begin{abstract}
Data Pasien Puskesmas Kibang Budi Jaya pada tahun 2015 menunjukkan terdapat sebanyak 4 (3,17\%) kasus kasus IMS. Kejadian IMS di salah satu Puskesmas Tulang Bawang Barat memiliki prevalensi kejadian IMS yang lebih tinggi. Tujuan penelitian ini adalah untuk mengetahui gambaran pengetahuan dan sikap tentangpenyakitIMS pada Ibu Rumah Tangga di Puskesmas Tulang Bawang Barat. Metode penelitian yang digunakan adalah deskriptif dengan menggunakan desaincrossectional. Subjek penelitian ini adalah ibu rumah tangga yang ada di Wilayah Kerja Puskesmas Kibang Budijaya. Teknik sampling menggunakan accidental sampling sehingga jumlah sampel yang diperoleh sebanyak 69 responden. Teknik analisis data yang digunakan adalah analisis univariat. Hasil penelitian menunjukkan proporsi responden didominasi responden yang berusia>16 tahun, berpendidikan rendah, berstatus menikah, berpengetahuan kurang tentang IMS dan sebagian besar memiliki sikap yang negatif tentang IMS. Penelitian ini menyarankan agar meningkatkan akses pelayanan dalam bentuk konseling kesehatan seksual di tempat-tempat atau kegiatan yang sudah umum ada, baik di Posyandu, maupun pemeriksaan VCT, dan pada saat pemeriksaan IVA, bidanjuga dapat mengambil peran aktif dalam rangka memberikan informasi IMS kepada ibu rumah tangga di wilayah kerja Puskesmas Kabupaten Tulang Bawang Barat.
\end{abstract}

Kata kunci: Infeksi Menular Seksual (IMS)

\section{LATAR BELAKANG}

Infeksi Menular Seksual (IMS) masih menjadi masalah kesehatan masyarakat yang ada di seluruh dunia, di Negara maju (industri) maupun di Negara berkembang. Tingginya prevalensi kejadian infeksi penyakit menular seksual tersebut berkaitan dengan praktek perilaku pencegahan IMS dan HIV/AIDS yang masih sangat rendah, seperti rendahnya angka pemakaian pelindung kondom pada saat berhubungan seksual,diperkirakan75$80 \%$ penularan terjadi melalui hubungan seksual dan 5-10\%diantaranya melalui hubungan homoseksual (Pusat Penelitian dan Pengembangan Pemberantasan Penyakit, Dep Kes RI 2005).

WHO memperkirakan setiap tahun terdapat kurang lebih 350 juta penderita baru IMS di negara berkembang termasuk Indonesia, prevalensi gonorrhea menempati tempat teratas dari semua jenis IMS yaitu $32,4 \%$, sifilis sebesar $21,7 \%$. Penderita IMS sebagian besarberada di
Asia Selatan dan Asia Tenggara yaitu sebanyak 151 juta, diikuti Afrika sekitar 70 juta, dan yang terendah adalah Australia dan Selandia Baru sebanyak 1 juta. Semakin lama jumlah penderita IMS semakin meningkat dan penyebarannya semakin merata di seluruh dunia. WHO memperkirakan morbiditas IMS di dunia sebesar \pm 250 juta orang setiap tahunnya. Peningkatan insidensi IMS ini terkait juga dengan perilaku berisiko tinggi yang ada di masyarakat dewasa ini (Widoyono, 2011).

Kejadian IMS di Indonesia cenderung meningkat secara keseluruhan (Gonore, Sifilis) tercatat pada tahun 2011 sebanyak 11.280 dari jumlah tersebut kasus ghonorrhea sebanyak $5.131(45,4 \%)$ kasus, sifilis sebanyak 4725 (41,8\%) kasus, dan pada tahun 2012 meningkat sebanyak 13.043 kasus yang terdistribusi sebanyak $6003(46,0 \%)$ kasus gonorrhea, 5216 (40,0\%) kasus sifilis (Kemenkes RI, 2010).

Catatan kasus IMS di Provinsi Lampung Tahun 2013 sebanyak 1674 
dengan rincian sebanyak $481 \quad(41,0 \%)$ kasus sifilis, 475 (40,5\%) kasus gonorrhea 91 (7,8\%), dan $127(10,8 \%)$ kasus IMS lainnya, sedangkan pada tahun 2014 ditemukan 1.393 kasus IMS dengan rincian $574(41,2 \%)$ sifilis, $511(36,7 \%)$ gonore dan $121(8,7 \%)$ kasus IMS lainnya pada tahun 2015 kejadian IMS sebanyak 365 kasus (Profil Dinas Kesehatan Provinsi Lampung, 2015).

Faktor yang dapat mempengaruhi tingginya insiden IMS, antara lain: Perubahan demografik secara luar biasa, meningkatnya jumlah penduduk dengan pesat, pergerakan masyarakat yang bertambah, dengan berbagai alasan. Misalnya : pekerjaan, liburan, pariwisata, rapat/kongres/seminar, kemajuan social ekonomi, terutama dalam bidang industry menyebabkan lebih banyak kebebasan social dan lebih banyak waktu yang terbuang. Perubahan sikap dan tindakan akibat perubahan - perubahan demografik di atas, terutama dalam bidang agama dan moral. Kelalaian beberapa Negara dalam pemberian pendidikan kesehatan dan pendidikan seks khususnya. Perasaan aman pada penderita karena kemudahan memperoleh obat antibiotik yang dijual bebas. Akibat dari pemakaian antibiotic tanpa petunjuk yang sebenarnya, maka timbul resistensi kuman terhadap antibiotic tersebut. Fasilitas kesehatan yang kurang memadai trutama fasilitas laboratorium dan klinik pengobatan. Banyaknya kasus asimtomatik, merasa tidak sakit, tetapi dapat menulari orang lain (Daili, 2010).

Data yang diperoleh di Kabupaten Tulang bawang barat pada tahun 2013 sebanyak 95 kasus dengan rincian sebanyak 32 kasus sifilis, 57 kasus gonorhe dan 15 kasus HIV AIDS, pada tahun 2014 sebanyak 7 kasus HIV AIDS, tahun 2015 sebanyak 8 kasus HIV AIDS. Hal ini menunjukkan adanya peningkatan kejadian IMS di Kabupaten Tulang Bawang Barat (Profil Dinas Kesehatan Kabupaten Tulang Bawang Barat, 2015).

Sebagai perbandingan hasil pre survey di Puskesmas Panaragan jaya tahun 2015 terdapat sebanyak $2(2,56 \%)$ kasus dari 78 kunjungan berupa penyakit IMS dengan jenis Sifilis dan gonore, sedangkan di Puskesmas Kibang Budi Jaya pada tahun 2015 terdapat sebanyak $4(3,17 \%)$ kasus, dari 126 kunjungan yaitu penyakit IMS dengan jenis Sifilis (Ditjen P2P Kemenkes RI, 2015).

Berdasarkan data tersebut diatas kejadian IMS di Puskesmas Kibang Budi Jaya memiliki prevalensi kejadian IMS yang lebih tinggi bila dibandingkan Puskesmas Panaragan Jaya hal tersebut mengindikasikan bahwa Puskesmas Kibang Budi Jaya merupakan puskesmas yang memiliki fasilitas lebih lengkap seperti pemeriksaan PAP Smear, sehingga indikasi terhadap kejadian IMS lebih dapat diketahui.

\section{METODE}

Rancangan penelitian yang digunakan adalah penelitian deskriptif yaitu suatu metode penelitian yang dilakukan dengan tujuan untuk membuat gambaran tentang suatu keadaan secara objektif. Penelitian dilakukan untuk memperoleh Gambaran Pengetahuan Dan Sikap Tentang Penyakit Infeksi Menular Seksual (IMS) Pada Ibu Rumah Tangga Di Puskesmas Tulang Bawang Barat. Analisis data yang digunakan dalam penelitian ini adalah deskriptif dengan analisis univariat yang dilakukan terhadap tiap variabel dari hasil penelitian, untuk mengetahui distribusi frekuensi variabel.

\section{HASIL}

\section{Analisis Univariat}

Tabel 1: Distribusi Frekuensi Ibu Rumah Tangga Berdasarkan Umur

\begin{tabular}{lcc}
\hline \multicolumn{1}{c}{ Usia } & $\mathrm{f}$ & $\%$ \\
\hline$>16$ tahun & 60 & 87 \\
\hline$\leq 16$ tahun & 9 & 13 \\
\hline Jumlah & 69 & 100 \\
\hline
\end{tabular}

Diketahui bahwa distribusi frekuensi umur ibu rumah tangga didominasi oleh 
responden yang berusia > 16 tahun yaitu sebanyak 60 orang $(87,0 \%)$.

Tabel 2: Distribusi Frekuensi Ibu rumah Tangga Berdasarkan Pendidikan

\begin{tabular}{lcc}
\hline \multicolumn{1}{c}{ Pendidikan } & f & $\%$ \\
\hline Rendah & 56 & 81,2 \\
\hline Tinggi & 13 & 18,8 \\
\hline Jumlah & 69 & 100 \\
\hline
\end{tabular}

Diketahui bahwa distribusi frekuensi tingkat pendidikan ibu rumah tangga lebih dari separuh berpendidikan rendah yaitu sebanyak 56 orang $(81,2 \%)$.

Tabel 3: Distribusi Frekuensi Ibu Rumah Tangga Berdasarkan Status Penikahan

\begin{tabular}{lcc}
\hline \multicolumn{1}{c}{ Status Pernikahan } & f & $\%$ \\
\hline Menikah & 53 & 76,8 \\
\hline Cerai/Janda & 16 & 23,2 \\
\hline Jumlah & 69 & 100 \\
\hline
\end{tabular}

Diketahui bahwa distribusi frekuensi status pernikahan ibu rumah tangga sebagian besar berstatus menikah yaitu sebanyak 53 orang $(76,8 \%)$.

Tabel 4: Distribusi Frekuensi Pengetahuan tentang Penyakit Infeksi Menular Seksual (IMS) pada Ibu rumah Tangga

\begin{tabular}{lcc}
\hline \multicolumn{1}{c}{ Pengetahuan } & f & $\%$ \\
\hline Kurang & 41 & 59,4 \\
\hline Cukup & 18 & 26,1 \\
\hline Baik & 10 & 14,5 \\
\hline Jumlah & 69 & 100 \\
\hline
\end{tabular}

Diketahui bahwa tingkat pengetahuan tentang penyakit Infeksi Menular Seksual (IMS) pada ibu rumah lebih banyak yang berpengetahuan kurang yaitu sebanyak $41(59,4 \%)$.

\section{PEMBAHASAN}

\section{Analisis Item}

Berdasarkan hasil analisis terhadap item pertanyaan maka diketahui bahwa pada pernyataan tentang pengertian penyakit ketika dinyatakan bahwa penyakit Infeksi Menular Seksual adalah penyakit yang menyerang pada alat kelamin perempuan atau laki-laki akibat melakukan hubungan seksual dinyatakan 'Ya' oleh sebanyak 26 (37,7\%) responden, dinyatakan tidak oleh sebanyak $19(27,5 \%)$ responden dan dinyatakan 'tidak tahu' oleh sebanyak $24(34,8 \%)$ responden. Hasil ini menunjukkan bahwa proporsi ibu rumah tangga yang mengetahui pengertian IMS lebih sedikit dibandingkan dengan ibu yang tidak mengetahui pengertian IMS.

Pada pernyataan tentang gejala ibu yang menderita penyakit Infeksi Menular Seksual adalah nyeri disekitar alat kelamin yang dinyatakan 'Ya' oleh sebanyak 17 $(24,6 \%)$ dan dinyatakan tidak tahu oleh 31 $(44,9 \%)$ responden serta dinyatakan tidak oleh sebanyak $21(30,4 \%)$ responden. Hasil ini menunjukkan bahwa banyak ibu yang kurang memahami bahwa salah satu gejala IMS adalah adanya nyeri di sekitar alat kelamin.

Pada pernyataan tentang apa yang harus dilakukan oleh penderita Penyakit Infeksi Menular Seksual agar sembuh dengan tidak berhubungan seksual samasekali dinyatakan oleh sebanyak 12 $(17,4 \%)$ yang menjawab ya sementara sebagian besar lainnya menjawab tidak dan tidak tahu. Data ini menunjukkan bahwa ibu rumah tangga banyak yang tidak mengetahui bahwa salah satu upaya tidak tertular IMS adalah dengan tidak melakukan hubungan seksual sama sekali.

Pengetahuan responden paling rendah tampak dari pernyataan; 'menurut ibu apa saja yang dapat menyembuhkan (IMS) yang dijawab dengan jawaban menggunakan obat kanker yang dinyatakan oleh $32(46,4 \%)$ dengan pernyataan tidak tahu. Pada pernyataan tentang HIV adalah virus yang mengganggu sistem kekebalan dalam tubuh manusia yang dapat menular melalui kontak dengan darah sebagian besar memberikan pernyataan tidak tahu yaitu sebanyak $40(58,0 \%)$.

Berdasarkan penjelasan dan hasil penelitian tentang pengetahuan di atas maka dapat diketahui ada beberapa 
pengetahuan yang kurang baik terkait dengan penyakit infeksi menular seksual yang perlu mendapat perhatian, yaitu tentang kurang pahamnya responden tentang apa yang harus dilakukan penderita IMS agar sembuh, kurangnya pengetahuan tentang bahwa HIV merupakan virus yang mengganggu sistem kekebalan dalam tubuh manusia yang dapat menular melalui kontak dengan darah, serta kurangnya pengetahuan obat dan langkah apa yang dapat dilakukan untuk menyembuhkan IMS.

Hasil analisis item sikap juga menggambarkan sikap reponden tentang Infeksi Menular Seksual (IMS). berdasarkan hasil penelitian diketahui bahwa pada pernyataan; 'menurut saya HIV/AIDS dapat disembuhkan dengan cara minum obat antibiotik' dijawab oleh responden dengan jawaban beragam, sebanyak $19(27,5 \%)$ menyatakan sangat setuju dan sebanyak 35 (50,7\%) menyatakan sangat tidak setuju. Hasil pernyataan sangat tidak setuju yang jumlahnya lebih banyak dari yang tidak setuju mengindikasikan bahwa responden banyak yang tidak memahami bahwa HIV/AIDS dapat disembuhkan dengan mengkonsumsi antibiotik merupakan pernyataan yang tidak sesuai atau kurang tepat.

Hasil penelitian menggambarkan proporsi ibu rumah tangga di Puskesmas Kibang Budi Jaya Kabupaten Tulang Bawang Barat Tahun 2017 lebih banyak didominasi oleh ibu rumah tangga yang berusia $>16$ tahun $(87,0 \%)$.

Distribusi umur yang paling banyak memiliki rentang umur antara $>16$ tahun menunjukkan bahwa masyarakat umumnya di Puskesmas Kibang Budi Jaya menjalankan perannya sebagai ibu rumah tangga dalam usia yang produktif. Dilihat dari aspek demografis diketahui perubahan sikap masyarakat tentang pernikahan yang kecenderungan usia menikah dilakukan setelah anak menyesaikan pendidikan atau tidak menikah dahulu sebelum bekerja.

Hasil penelitian ini sejalan dengan hasil penelitian Putri (2015) yang menghasilkan proporsi dari penelitiannya bahwa responden memiliki usia > 16 Tahun yaitu sebesar $71.3 \%$, sedangkan usia <16 Tahun sebesar 28.8\%. Hasil penelitian tidak sejalan dengan teori Noor (2007) menyatakan bahwa umur adalah lama waktu hidup atau ada. Umur merupakan salah satu sifat karakteristik tentang orang yang sangat utama. Umur mempunyai hubungan dengan tingkat keterpaparan, besarnya rresiko serta sifat resistensi.

Secara konseptual umur didefinisikan dengan adalah satuan waktu yang mengukur waktu keberadaan suatu benda atau makhluk, baik yang hidup maupun yang mati. Menurut Andri (2009) yaitu usia turut mempengaruhi seseorang dalam mempersepsi suatu objek yang memungkinkan seseorang memeproleh pengalaman serta pengetahuan yang lebih luas, oleh karenanya usia ibu dijadikan sebagai salah satu indikator yang memungkinkan seseorang mendapatkan stimuli yang menginformasikan sesuatu untuk memperoleh pengalaman yang baru.

Berdasarkan pemaparan tersebut penulis berpendapat bahwa umur atau usia ibu akan mengantarkan ibu untuk memahami tentang penyakit Infeksi Menular Seksual (IMS). Secara kontekstual dapat dijelaskan bahwa beda usia, beda pula risiko dan kondisi yang akan dialami baik dari aspek fisiologis, aspek psikologis dan aspek lainnya. Secara fisiologis usia berhubungan dengan struktur organ, fungsi faal, komposisi biokimiawi termasuk sistem hormonal seorang wanita. Perbedaan fungsi faal, komposisi biokimiawi, dan sistem hormonal pada suatu periode umur menyebabkan perbedaan pada kontrasepsi yang dibutuhkan oleh masing-masing umur dan keseluruhannya berkaitan dengan perannya sebagai ibu rumah tangga. Secara psikologis usia berkaitan dengan pengalaman, lingkungan, dan proses belajar yang dialaminya, sejauh dan sebanyak apa informasi tentang infeksi menular seksual yang bisa diperoleh oleh individu. 


\section{Pendidikan}

Berdasarkan hasil penelitian diperoleh gambaran bahwa distribusi frekuensi tingkat pendidikan ibu rumah tangga di Puskesmas Kibang Budi Jaya Kabupaten Tulang Bawang Barat Tahun 2017 lebih dari separuh berpendidikan rendah yaitu sebanyak 56 orang $(81,2 \%)$.

Hasil penelitian tersebut mengidikasikan bahwa responden lebih banyak yang berpendidikan rendah. Pendidikan rendah pada penelitian ini adalah pendidikan SMA ke bawah, artinya meskipun proporsi pendidikan rendah, penduduk khususnya ibu rumah tangga sudah banyak yang berpendidikan SMA.

Hasil penelitian tidak sejalan dengan hasil penelitian Romadaniah (2013) yang menggambarkan proporsi ibu rumah tangga yang pendidikan rendah lebih sedikit jumlahnya $(30,1 \%)$ dibandingkan yang berpendidikan tinggi. Perbedaan ini dapat saja terjadi karena perbedaan lokasi penelitian yang mencakup kultur, tradisi, kondisi sosial demografis yang berbeda antara satu wilayah dengan wilayah lainnya. Hakikatnya pengetahuan tetap memberikan kontribusi terhadap bagaimana seseorang memberikan respon terhadap objek tertentu.

Faktor pendidikan ini menurut Notoatmodjo (2010) dianggap penting karena dari pendidikan seseorang dapat mengetahui dan melaksanakan perannya secara sosial. Pendidikan adalah upaya persuasi atau pembelajaran kepada masyarakat agar mau melakukan tindakan (praktik) untuk memelihara untuk mengatasi masalah-masalah dan untuk meningkatkan kesehatannya.

Hasil penelitian ini sejalan dengan penelitian penelitian Sugiharti dan Lestari (2008) yang menyimpulkan bahwa pendidikan seseorang dapat mendorongnya untuk melakukan seusatu yang berkaitan dengan kesehatannya. Hasil penelitian Reihana (2011) menyatakan bahwa pendidikan yang tinggi mempunyai peluang 2,7 kali untuk mempunyai partisipasi dalam melakukan perilaku seksual yang sehat
Dari penjelasan diatas dapat menurut pendapat peneliti bahwa tingkat pendidikan tetap menjadi elemen penting dalam pembentukan perilaku yang secara spesifik diimplementasikan pada perilakunya yang tidak menuju pada perilaku risiko kejadian IMS, dari pendidikan distribusi informasi dan pesan diolah semakin rendah pendidikan maka arus informasi dan pesan tentang objek menjadi terbatas sedangkan semakin tinggi tingkat pendidikan seseorang berarti memiliki potensi memperoleh informasi dan pesan yang lebih luas. Tingkat pendidikan berpengaruh terhadap pengetahuan, sikap dan perilaku seksual seseorang sehingga sangat berasosiasi kuat dengan kejadian IMS. Kerentanan seseorang karena rendahnya tingkat pendidikan membuat seseorang mengalami defisit informasi tentang IMS termasuk cara penularan dan pencegahannya. Padahal tanpa tahu cara penularan dan pencegahan yang tepat, mustahil seseorang dapat melindungi diri dari risiko tertular IMS.

Berdasarkan pemaparan tersebut maka penulis berpendapat bahwa pendidikan merupakan salah satu faktor predisposisi untuk terjadinya perubahan prilaku pada seseorang, artinya bahwa ibu dengan tingkat pendidikan yang lebih tinggi akan menjadikan ia menjalankan peran sebagai ibu rumah tangga secara baik dan melakukan upaya pencegahan terhadap penularan infeksi penyakit menular seksual.

Berdasarkan distribusi dan proporsi yang diperoleh ternyata lebih banyak ibu yang memiliki tingkat pendidikan menengah namun tidak sedikit pula yang memiliki tingkat pendidikan rendah, hal tersebut menunjukkan bahwa tingkat pendidikan masyarakat secara umum kurang baik. Kondisi demografis yang dilihat dari sisi pendidikan ini dapat memberikan sumbangsih dan potensi bahwa masyarakat akan mudah menerima dan merespon informasi yang berkaitan dengan perilaku kesehatan secara lebih terbuka. Pada kenyataannya perbedaan pendidikan seseorang akan membedakan 
sejauhmana respon seseorang terhadap informasi atau objek baru khususnya yang berkaitan dengan perubahan perilaku kesehatan.

\section{Status Pernikahan}

Hasil penelitian menunjukkan proporsi status penikahan ibu rumah tangga dimana sebagian besar berstatus menikah yaitu sebanyak 53 orang $(76,8 \%)$.

Secara konseptual dijelaskan bahwa status menikah adalah ikatan lahir batin antara seorang pria dengan seorang wanita sebagai suami isteri dengan tujuan membentuk keluarga (rumah tangga), hal ini dijelaskan dalam Pasal 1 UU No 1 tahun 1974 tentang Perkawinan. Jika dikaitkan dengan masalah penelitian maka status pernikahan berarti mengumpulkan data tentang status marital responden sesuai dengan kategori menikah, cerai atau janda yang ditinggal mati pasangannya.

Kondisi yang diperoleh dari hasil penelitian dapat memberikan gambaran bahwa secara marital, risiko IMS masih dapat diantisipasi, mengingat IMS lebih banyak terjadi pada status marital tidak atau belum menikah. Hal ini sejalan dengan penelitian Murtyastutik (2007) meneliti tentang penderita Gonore di Divisi Penyakit Menular Seksual Unit Rawat Jalan Ilmu Kesehatan Kulit dan Kelamin RSU Dr. Soetomo Surabaya Tahun 20022006 menjelaskan hasil penelitian bahwa angka kejadian Gonore pertahunnya dalam kurun waktu 2002-2005 relatif stabil.

Hasil penelitian ini sesuai dengan Penelitian Chatarina 2003 bahwa Insiden IMS lebih tinggi pada orang yang belum menikah, bercerai, atau orang yang terpisah dari keluarganya bila dibandingkan dengan orang yang sudah kawin.

Berdasarkan penjelasan tersebut maka menurut peneliti bahwa penularan penyakit IMS biasanya terjadi karena seringnya seseorang melakukan hubungan seksual, ikatan perkawinan yang dilakukan seseorang seharusnya dianggap sebagai ikatan agung yang harus dijaga, oleh karenanya status menikah menjadi penghalang seseorang untuk melakukan hubungan seksual secara bebas, namun jika statusnya tidak menikah dapat lebih mudah membawanya kepada perilaku seksual yang tidak mempertimbangkan risiko tertular IMS

\section{Pengetahuan}

Berdasarkan hasil penelitian diperoleh hasil bahwa tingkat pengetahuan tentang penyakit Infeksi Menular Seksual (IMS) pada ibu rumah tangga di Puskesmas Kibang Budi Jaya Kabupaten Tulang Bawang Barat Tahun 2017 lebih banyak yang berpengetahuan kurang yaitu sebanyak $41(59,4 \%)$.

Hasil Penelitian ini Romadaniah (2013) yang menghasilkan gambaran pengetahuan responden yang lebih didominasi oleh pengetahuan kurang $(58,1 \%)$, menurut penelitian ini kurangnya pengetahuan responden karena kurangnya paparan informasi yang diterima oleh responden. Penelitian Fatimah (2013) menggambarkan bahwa sebagian besar responden yang menjadi objek penelitiannya memiliki tingkat pengetahuan cukup mengenai IMS. Dari kedua hasil penelitian tersebut dapat diketahui bagaimana pengetahuan orang bisa saja berbeda tergantung dari bagaimana informasi tersebut diterima dan disebarkan kepada mereka. Penelitian yang dilakukan sebelumnya oleh Panenga (2014), sesuai dengan hasil penelitian ini yaitu pengetahuan responden mengenai penyakit menular seksual paling banyak berada pada kategori cukup $56.05 \%$.

Secara konseptual Notoadmojdo (2010) menyatakan bahwa pengetahuan adalah hasil pengindraan manusia atau hasil tahu seseorang terhadap objek melalui alat indra (mata, hidung, telinga, dan sebagainya) (Notoadmodjo, 2010). Hal yang dimaksud tahu disini responden dapat mengetahui segala bentuk informasi tentang IMS. Cara pengukuran pengetahuan dapat dilakukan dengan berbagai cara, antara lain dengan membedakan tingkat pendidikan, wawancara, angket, mengamati 
(mengobservasi) perilaku seseorang terhadap suatu pemecahan masalah dan melakukan pengujian (test) pengetahuan (Notoatmodjo, 2012)

Pengetahuan responden tentang IMS yang rendah disebabkan karena respon responden yang cenderung pasif terhadap informasi tentang IMS, karena umumnya dipahami bahwa IMS hanya bisa terjadi pada orang-orang yang memiliki perilaku seksual yang menyimpang atau perilaku berganti-ganti pasangan yang hanya terjadi pada wanita pekerja seksual atau laki-laki hidung belang.

Perbedaan hasil penelitian satu dengan lainnya termasuk dengan hasil penelitian ini bisa disebabkan oleh penggunaan parameter yang berbeda dan sampel yang digunakan. Secara teoritis pengetahuan merupakan pengertian atau mengerti benar tentang sesuatu. Pengertian dapat juga diartikan sebagai penerimaan dengan cermat dari stimuli atau isi pesan secara cermat dari apa yang disampaikan (Notoatmodjo, 2010).

Berdasarkan penjelasan tersebut maka penulis berpendapat bahwa pengetahuan sangat penting dalam membentuk sikap dan perilaku, terutama berkaitan dengan upaya pencegahan agar tidak terpapar penyakit infeksi menular seksual pada ibu rumah tangga. Pengetahuan yang benar akan menghasilkan perilaku yang benar. Masih adanya responden yang memiliki pengetahuan rendah sudah selayaknya mendapatkan perhatian dengan memperluas sasaran target promosi kesehatan tentang IMS kepada sasaran yang lebih luas. Selama ini promosi kesehatan atau penyuluhan tentang IMS hanya intens dilaksanakan kepada kelompok risiko tinggi seperti para pelaku seks menyimpang atau remaja, padahal ibu rumah tangga juga memiliki risiko yang sama karena berkaitan dengan perilaku seksualnya sendiri atau perilaku seksual dengan pasangannya.

\section{Sikap}

Berdasarkan hasil penelitian diperoleh hasil bahwa distribusi frekuensi sikap tentang penyakit Infeksi Menular Seksual (IMS) pada ibu rumah tangga di Puskesmas Kibang Budi Jaya Kabupaten Tulang Bawang Barat Tahun 2017, dimana sebagian besar memiliki sikap yang negatif yaitu sebanyak 48 orang $(69,6 \%)$.

Notoatmodjo (2012) mendefinisikan bahwa sikap seseorang adalah predisposisi (keadaan mudah terpengaruh) untuk memberikan tanggapan terhadap rangsangan lingkungan, yang dapat memulai ataupun membimbing tingkah laku orang tersebut. Sikap juga didefinisikan sebagai evaluasi umum yang dibuat manusia terhadap dirinya sendiri, orang lain, objek atau issue. Sikap adalah merupakan reaksi atau respon seseorang seseorang yang masih tertutup terhadap stimulus serta pandangan atau perasaan yang disertai kecendrungan untuk bertindak sesuai objek tersebut.

Mengenai sikap ini, temuan-temuan penelitian mengenai sikap menghasilkan proporsi atau gambaran yang beragam. Banyak penelitian yang menyimpulkan adanya proporsi yang lebih didominasi dengan sikap responden yang negatif terhadap kejadian IMS atau penelitian lain menunjukkan proporsi yang sebaliknya. Penelitian Fatimah (2013) yang menghasilkan gambaran sikap positif lebih mendominasi dibandingkan responden yang bersikap kurang baik yaitu $(70 \%)$ dari 50 responden yang diteliti.

Berdasarkan hasil penelitian tersebut maka penulis berpendapat bahwa sikap dapat memberikan efek secara psikologis terhadap perubahan perilaku dalam hal ini adalah pencegahan terhadap IMS. Oleh karenanya intervensi promosi kesehatan yang dapat dilakukan adalah memformulasikan bentuk, cara, dan strategi promosi kesehatan yang mengacu pada 3 domain psikologis yaitu perubahan kognitif, perubahan afektif dan perubahan psikomotor dengan demikian dari pengetahuan yang diperoleh responden akan membentuk sikap positif tentang IMS kemudian mendorong responden melakukan pencegahan dan upaya agar terhidan dari paparan IMS. 
Banyak

kondisi-kondisi

ketergantungan yang dapat mengubah sikap individu. Oleh karena itu, sejauh mana prediksi perilaku dapat disandarkan pada sikap akan berbeda dari waktu ke waktu dan dari satu situasi ke situasi lainnya. Sikap merupakan reaksi atau respon yang masih tertutup dari seseorang terhadap stimulus atau objek. Sikap membuat seseorang mendekati atau menjauhi orang lain atau objek lain, tetapi sikap yang positif atau mendukung terhadap nilai-nilai kesehatan tidak selalu terwujud dalam tindakan nyata.

Terbentuknya suatu sikap banyak dipengaruhi oleh faktor perangsang yang timbul di lingkungan sosial dan juga kebudayaan misalnya keluarga, norma, adat istiadat dan kepercayaan. Sikap seseorang tidak selalu menjelma dalam bentuk perbuatan atau tingkah laku tindakan. Hal ini disebabkan karena sikap akan terwujud di dalam suatu tindakan tergantung pada situasi saat itu, misalnya seseorang yang memiliki sikap positif terhadap pencegahan Infeksi Menular Seksual untuk menjaga kesehatan.

Sikap akan diikuti atau tidak diikuti oleh tindakan, mengacu kepada pengalaman orang lain. Seseorang akan melakukan upaya pencegahan ketika mendapatkan informasi bahwa ibu rumah tangga juga bisa saja terpapar IMS. Sikap juga dapat diikuti atau tidak diikuti oleh suatu tindakan berdasarkan pada banyak atau sedikitnya pengalaman seseorang, misalnya jika keluarga atau teman mengalami keputihan setelah menggunakan salah satu permbersih cair, maka seseorang kemudian menggunakan sabun pembersih lain untuk digunakan. Nilai-nilai di masyarakat apapun selalu berlaku nilai-nilai yang menjadi pegangan setiap orang dalam menyelenggarakan hidup bermasyarakat.

\section{KESIMPULAN}

Penelitian ini menyimpulkan bahwa umur didominasi oleh responden yang berusia > 16 tahun yaitu sebanyak 60 orang $(87,0 \%)$, tingkat pendidikan ibu rumah tangga, lebih dari separuh berpendidikan rendah yaitu sebanyak 56 orang $(81,2 \%)$ dan distribusi frekuensi status pernikahan ibu rumah tangga sebagian besar berstatus menikah yaitu sebanyak 53 orang $(76,8 \%)$.

Tingkat pengetahuan tentang penyakit Infeksi Menular Seksual (IMS) pada ibu rumah tangga lebih banyak yang berpengetahuan kurang yaitu sebanyak 41 $(59,4 \%)$. Terdapat beberapa pengetahuan yang kurang baik terkait dengan IMS yang perlu mendapat perhatian, yaitu kurang pahamnya responden tentang apa yang harusdilakukanpenderitaIMS agar sembuh, kurangnya pengetahuan tentang bahwa HIV merupakan virus yang mengganggusistemkekebalandalamtubuhm anusia yang dapatmenularmelalui kontakdengandarah, serta kurangnya pengetahuan tentang upaya apa yang dapatdilakukan untuk menyembuhkanIMS.

Sikap tentang penyakit Infeksi Menular Seksual (IMS) pada ibu rumah tangga sebagian besar memiliki sikap yang negatif yaitu sebanyak 48 orang $(69,6 \%)$. Terdapat beberapa pernyataan sikap negatif yang tergambar dari jawaban responden yang meliputi beberapa hal, yaitu kesalahpahaman bahwa HIV/AIDS dapat disembuhkan dengan obat antibiotik, ketidaknyamanan dalam penggunaan kondom saat berhubungan seksual dan kurangnya pemahaman tentang perlunya menghindari penggunaan pisau cukur bersama-sama untuk menghindari penularan IMS melalui kontak darah.

Berdasarkan pada kesimpulan yang telah diuraikan penulis menyarankan agar petugas kesehatan di Puskesmas melakukan penyuluan kesehaatan kepada ibu rumah tangga di Wilayah yang berpotensi tinggi terhadap kejadian IMS yang materinya lebih banyak difokuskan pada upaya dan langkah kesembuhan, penyuluhan tentang HIV/AIDS dan cara 
penularan dan langkah pencegahannya baik melalui informasi tentang tindakan medis apa yang harus dilakukan atau dengan merubah perilaku penderita IMS. Materi-materi tersebut perlu dirangkum menjadi tulisan dalam bentuk leaflet kemudian dibagikan kepada ibu rumah tangga.

\section{DAFTAR PUSTAKA}

Azizah, Noor. 2007. Keefektifan Penggunaan Model Pembelajaran Kooperatif Tipe NHT (NumberedHead-Together). Skripsi UNNES.

Chatarina, W, U,. 2003. Faktor-Faktor Yang Mempengaruhi Terjadinya Infeksi HPV 16/18. 2003. http://adln.lib.unair.ac.id

Daili, SF, 2010. Tinjauan Penyakit Menular Seksual dalam Ilmu Pemyakit Kulit dan Kelamin. Balai Penerbit FKUI. Jakarta

DepKes RI 2005. Pusat Penelitian dan Pengembangan Pemberantasan Penyakit, Direktorat Jenderal PPM \& PLP. Jakarta

Ditjen P2P Kemenkes RI, 2015. Pencegahan dan Pengendalian Penyakit. Jakarta

Fatimah,S. 2013. Hubungan Antara Pengetahuan Dan Sikap Pasien Infeksi Menular Seksual (Ims) Dengan Perilaku Pencegahan
Penularan IMS di Wilayah Kerja Puskesmas Kom Yos Sudarso Pontianak. Tanjung Pura

Notoatmodjo. Soekidjo. 2012. Promosi Kesehatan dan Perilaku Kesehatan Rineka Cipta. Jakarta

Notoatmodjo, Soekidjo. 2010. Pendidikan dan Perilaku Kesehatan. PT. Rineka Cipta. Jakarta.

Dinkes Provinsi Lampung. 2016. Profil Dinas Kesehatan Provinsi Lampung tahun 2015.

Dinkes Kab. Tulang Bawang. 2016. Profil Dinas Kesehatan Kabupaten Tulang Bawang Barat tahun 2015.

Panenga,T.D,. Noor, MR., \& Triwanti. 2014. Tingkat pengetahuan Tentang Penyakit Infeksi Menular Seksual Pada Siswa SMA Di Banjar Masin. Jurnal Berkala Kedokteran, Vol 1 (2); 95-101

Putri, NT,. 2015. Tingkat pengetahuan Remaja tentang infeksi menular seksual. Cinebong bogor

Reviliana, dkk. 2011.Faktor-faktor Yang Mempengaruhi Tingginya Kejadian Infeksi Menular Seksual Di Lokalisasi Gang Sadar Baturaden Kota Banyumas

Romadaniah, A,R,. 2013.Gambaran Pengetahuan Ibu Tentang Hiv/Aids Dan Faktor-Faktor Yang Berhubungan Di Uptd Puskesmas Pondok Gede. Kota Bekasi 